\title{
Dimensions of Emancipation: Rethinking Subjectivity, Domination and Temporality in Feminist Theory
}

\author{
Susanne Lettow, Freie Universität Berlin
}

\begin{abstract}
"Emancipation" is one of the most opaque words in political language and political theory. It refers to the hope of overcoming all forms of domination, yet is articulated with the highly ambivalent notions of reason, progress, equality and liberty, and with the unfulfilled utopias that accompany them. In light of the different and contested uses that have been made of the concept of emancipation within and beyond contemporary feminist theory, I argue that a close examination of the concept and of the unresolved political and theoretical questions it articulates is a timely endeavour. With reference to Reinhard Koselleck's conceptual history of emancipation, in which he highlights three developments that helped to shape the modern concept of emancipation - first, the turn towards a reflexive understanding of emancipation as self-emancipation; second, the politicisation of the concept; and third, its temporalisation - I examine the ways in which subjectivity, domination and temporality have been articulated in contemporary feminist theory.
\end{abstract}

Keywords: subjectivity, domination, temporality, contemporary feminist theory, emanicipation

"Emancipation" is one of the most opaque words in political language and political theory. It refers to the hope of overcoming all forms of domination, yet is articulated with the highly ambivalent notions of reason, progress, equality and liberty, and with the unfulfilled utopias that accompany them. Since the late eighteenth century, the concept of emancipation has played a central role in the political language of feminist and other social movements. Although 
the different uses that have been made of the concept seem to converge and gravitate around common themes, "emancipation" has not, however, acquired a specified meaning, neither in the formative contexts of the nineteenth century nor through the usages that developed over the centuries that followed. Surprisingly, political and social theorists have paid little attention to the concept of emancipation and its theoretical conundrums in contrast to other political-theoretical concepts such as, for example, freedom, justice or equality. Or when they did, it was mainly from a critical perspective.

In the early 1990s, Ernesto Laclau formulated a powerful critique of the concept of emancipation, arguing that the very idea of emancipation is based on a linear view of history as progress, a rationalist idea of the subject, and an understanding of power and domination in terms of repression and alienation. All these assumptions, he proposed, rely on unquestioned, essentialist foundations, and thus foster totalising, if not totalitarian, ways of understanding the social and the political. In a similar vein, Judith Butler equated "emancipation" with a representational understanding of politics and a juridical model of the subject. "Feminist critique," she argued, should in contrast, "understand how the category of 'women,' the subject of feminism, is produced and restrained by the very structures of power through which emancipation is sought" (Butler 1990, 2). In light of these critiques, the concept of emancipation seemed to be obsolete.

However, the concept did not vanish entirely from feminist discourse. In the heated debates on feminism and postmodernism during the 1990s, Seyla Benhabib, for example, warned that this alliance might "place in question the very emancipatory ideals of the women's movements altogether" (Benhabib 1995, 22). Wendy Brown asked how one could "conjure an emancipatory future" while living in the "broken narratives" of modernity (Brown 2001, 14). In addition, the concept of emancipation has recently made a new appearance in feminist debates. Most prominently, Nancy Fraser has proposed emancipation as a political strategy beyond neoliberal marketisation and state paternalism. From a more sceptical point of view, Joan Scott has critically analysed the "work the language of emancipation and equality is doing" (Scott 2012, 162 ) in the present, when emancipation is no longer conceived of as a political claim or result of political struggle, but as a quality that inheres in persons or groups of persons. "From this perspective," Scott argues, "emancipation is not a matter of being free of prior impediments, but of understanding oneself in modern Western terms" (ibid., 152). Despite the ideological workings of the notions of emancipation and equality, however, Scott also evokes a possible positive meaning of emancipation. With reference to the early Marx's notion of "human emancipation," she appeals for a re-politicisation of the notion in order to "forge a genuine political community dedicated to achieving greater measures of social equality" that do not erase differences (ibid., 165). 
In light of these different and contested uses that have been made of the concept of emancipation within and beyond contemporary feminist theory, I think that a close examination of the concept and of the unresolved political and theoretical questions it articulates is a timely endeavour that contributes to the re-politicisation of feminist theory. In what follows, I argue that "emancipation" is enmeshed with pressing questions about subjectivity, domination and temporality. I thereby build on Reinhard Koselleck's account of the conceptual history of emancipation in which he highlights three developments that helped to shape the modern concept of emancipation. These are, first, the turn towards a reflexive understanding of emancipation as self-emancipation; second, the politicisation of the concept; and third, its temporalisation. With reference to Koselleck's analysis, I examine the ways in which these dimensions have been articulated in contemporary feminist theory.

In the first part, I scrutinise the understanding of subjectivity in terms of subjection. By focusing primarily on the incorporation and re-iteration of norms, this theoretical orientation tends to neglect processes of transgression or of disentanglement and dis-attachment from structures of domination. I argue that a theory of subjectivity is needed that highlights the capacities of "re-doing" the demos ${ }^{1}$ and thus by reshaping oneself and social relations reshaping democratic political engagement. I thereby draw on insights formulated in affect studies and in the political theory of Antonio Gramsci.

In the second part, I discuss prevalent understandings of power in contemporary feminist theory, and argue that a theoretically sound notion of domination is needed, firstly, in order to overcome tendencies towards a culturalisation and racialisation of gendered forms of domination and, secondly, with respect to an integral understanding of capitalism. In the third part, I finally argue that the anticipatory, future-oriented aspect of emancipation can and should be re-conceptualised without falling back on notions of linear time. While poststructuralist critiques of linear time have successfully deconstructed the "grand narrations" of progress and revolution, they have tended to downplay the temporal dimension of the future. I argue that, both from the perspective of an encompassing theory of domination and from the perspective of a politics of subjectivity that highlights potentials for individual and collective self-transformation, it is relevant to rethink the temporality of social and political transformation. Although my reflections on subjectivity, domination and temporality do not lead to a full-fledged theory of emancipation I conclude that this concept and its ambiguous and polyvalent history can serve as a theoretical catalyst that helps to reshape the political-theoretical language of feminism. 


\section{Emancipation as a politics of subjectivity}

In his conceptual history of emancipation, Reinhard Koselleck has stressed that the meaning of "emancipation" underwent significant change in the late eighteenth and early nineteenth centuries. In Roman Law, emancipation meant the father's legal act of accrediting maturity to his son. In the context of social and political movements such as the Jewish emancipation vis-à-vis the Christian state around 1800, the emancipation of the Catholics in England, abolitionism, or the early socialist and women's movements, however, the original legal meaning of emancipation changed. In particular, "emancipation" no longer referred to a legal act by a sovereign, be it the paterfamilias or the state, but came to be understood as a political process of transformation that included a process of self-transformation. As Koselleck puts it, the term became "reflexive" in the grammatical sense of the word: it was no longer about emancipating someone else, but about emancipating or empowering oneself. An early indicator of this process can be found in a French dictionary from the early eighteenth century in which the author explains that emancipation means "to give oneself too much freedom" or to "shed all subservience" (Koselleck and Grass 1992, 159). Emancipation in the modern sense of the term thus came to designate a process of becoming noncompliant, or of not responding to ideological interpellations. In his 1784 essay An Answer to the Question: What is Enlightenment? Kant framed this process as the overcoming of "self-incurred immaturity," stressing that social transformation cannot be reduced to a political revolution but requires a self-transformation that he equates with the courage to "use one's own understanding without the guidance of another" (Kant 1784/2003, 54).

Although Kant, who did not use the term "emancipation," built on a rationalist notion of individual autonomy, he grasped an important dimension of the process of emancipation, namely the fact that it is a process which necessarily requires some sort of self-transformation. Kant speaks of "cowardice" and "laziness" that have to be overcome through "courage". This certainly does not capture the complexity and the ambivalences of overcoming subjection, and the idea that rationality, and the public sphere - understood as an assemblage of autonomous moral agents - were themselves structured through forms of power and domination, was obviously beyond the scope of his argument. However Foucault in his reading of Kant's essay rightly highlighted the fact that Kant articulates a politics of subjectivity. Foucault reformulated this as a "critical ontology of ourselves ... in which the critique of what we are is at one and the same time the historical analysis of the limits that are imposed on us and an experiment with the possibility of going beyond them" (Foucault 1984, 14). Diana Coole therefore speaks of the "Kantian-Foucauldian sense of 
emancipation as an ongoing process of becoming" (Coole 2015, 532) which she specifies as a "critical ethos". This ethos, Coole explains from an existentialist perspective, is a certain "way of (co-)existing in which taken for granted assumptions, identities, habits, embodied styles, everyday conduct, are simultaneously implicated in, and continually called upon, as the medium for a relentless process of denaturalization, expressive improvisation, and experimental reinvention" (ibid., 536).

Such a politics of subjectivity has been crucial for the various feminist movements since the nineteenth century because these movements did not only seek to change legal frameworks and economic conditions but also daily modes of living, of self-perception and habitus. Coole refers to the politics of consciousness-raising that was developed in the Anglophone women's movements of the 1970s, but other examples could be drawn from the history and present of feminism. Indeed, Judith Butler's concepts of gender performativity and resignification build on the insight that the subversion of domination requires the subjects themselves to change even if they cannot escape or "liberate" themselves from structures of power. In so far as "bodies never quite comply with the norms by which their materialization is impelled" they have the potential "to spawn rearticulations that call into question the hegemonic force of that very regulatory law" (Butler 1993, 1). The modifications of the ways in which bodies relate to the norms can thus induce a destabilization of the supra-individual order of "the law" - although they cannot overthrow it.

From the perspective of critical theory, Amy Allen has framed this as an understanding of emancipation "without utopia". A Foucauldian-Butlerian idea of emancipation cannot, as Amy Allen has put it, "refer to a utopian form of social life beyond or outside of power relations, but rather envisions the radical transformation of a state of gender domination into mobile, reversible, and unstable relations of power that are also practices of freedom" (Allen 2015, 517). Like Coole, Allen highlights the fact that Foucault and Butler rearticulate central aspects of emancipation and indeed envision social, cultural and political change. However she also argues that Butlerian and Foucauldian understandings of subjectivity, which have inspired feminist theory during the last decades, primarily emphasise the ways in which norms and power relations are assumed, incorporated and reiterated. As a consequence, critical analyses of the production of consensus and compliance with social norms and orders have proliferated, whereas the study of dissent, rejection and resistance has been marginalised. Allen explicitly discusses this problem in her book The Politics of Ourselves, and formulates the task "to envision subjects as both culturally constructed in and through relations of power and yet capable of critique" and of overcoming subjection (Allen 2008, 21). Accordingly, if one does not want to fall back on a liberatory, voluntarist vocabulary and the 
illusion of individual autonomy, the question arises of how to develop a new theoretical understanding of the transgressive potentials of subjectivity. Allen here draws on Butler's analysis of desire and argues, that "questions of will and desire" need to be incorporated into a Habermasian account of autonomy so that "the prospects for reworking will and desire in a direction that motivates emancipatory self-transformation" can be better understood (ibid., 12). However, I think that instead of reconciling Habermasian and Butlerian perspectives, both need to be transformed in order to rethink the transgressive potentials of subjectivity.

In my view, affect studies provide productive impulses in this respect in so far as they acknowledge the fact that affects can work in both directions, i.e. towards stabilising attachments to bad and painful situations or subordinate positions, but also towards dissent and transgression. As Brigitte Bargetz has highlighted, in order to understand the way in which emancipation is "working through affect and emotion" (Bargetz 2015, 92-3) the political ambivalence of emotions needs to be taken into account. Neither "romantizicing" (ibid., 81) the workings of affects, nor a purely critical stance towards the ideological forms of affect politics is adequate. What is needed is a critical understanding of affects that reveals their potential to disrupt established modes of relating to oneself and to others. In particular, negative affects such as despair, feelings of failure and fear contain an emancipatory potential. Unhappiness, as Sara Ahmed puts it, "may also provide an affective way of sustaining our attention on the cause of unhappiness" (Ahmed 2010, 75). It can have a criticalepistemic dimension in so far as it may provide the insight that "unhappiness is structured and that what happens to us might be connected in some way to what happens to others" (ibid., 87). This does not necessarily mean that unhappiness or other negative affects lead to rational insights but that certain ways of dealing with affects can result in the creation of new horizons of agency. "Feminist subjects" who take their feelings of discontent seriously, Sara Ahmed stresses, "in refusing to be well-adjusted not only mourn the losses" of missed or unrealized possibilities, "but in mourning open up other possibilities for living" (ibid., 79).

This, of course, is not an immediate or automatic result. In contrast, emancipation understood as a politics of subjectivity requires an active re-working of affects and attachments which aligns with a collective "politics of needs interpretation" and a contestation of the ways in which needs, desires and affects are politically articulated. As Nancy Fraser argued in the context of feminist debates on the welfare state in the late 1980s, not only the means of satisfaction but the needs themselves are constantly being interpreted and contested. What counts as a need? Who succeeds in presenting particular needs as relevant and pressing? By what means and strategies do other needs appear as less important or negligible, or get totally omitted from the discussion? Obviously, 
these questions require a critical analysis of the institutions through which authoritative interpretations are developed, as well as a politics that challenges the sedimented structures of needs interpretations. In addition, it is important to analyze the ways in which needs are co-constituted through the "distribution of emotions". ${ }^{2}$ Re-working and re-articulating affects, needs and desires thus means both, to re-shape oneself and to re-shape the social infrastructures of their production.

From this point of view, the main problem that a theory of subjectivity has to solve is not how to conceptualise critique and subversion in the absence of an "outside" of power - a problem that, for decades, has bothered feminist theorists working in the tradition of critical theory. The challenge, in my view, is to understand how individual and collective, personal and societal processes of transformation are entangled and interfere with one another. For this purpose, some insights can be drawn from Antonio Gramsci's political philosophy. In particular, his concept of the individual as a "historical bloc" seems to be helpful because it overcomes the conceptual separation between the individual and the social, the personal and the political. According to Gramsci, the individual is an assemblage "of purely individual and subjective elements and of mass and objective or material elements with which the individual is in an active relationship" (Gramsci Q 10 II, $\$ 48,682$ ). This means that subjectivity is in fact shaped through a "series of active relations" (ibid. \$54, 669) through which the individual engages with others, albeit to different degrees. Some of these relations are more concrete and personal while others are more abstract. The "synthesis of the constituting elements is 'individual,' but it cannot be realised and developed without an activity directed outward, modifying external relations both with nature and, in varying degrees, with other humans ${ }^{3}$, from the various social circles in which one lives, up to the greatest relationship of all, which embraces the whole human species" (ibid. $\$ 48$, 682). It is on this conceptual basis that Gramsci conceives of the co-constitution of individual and political agency. Political activity that is geared towards changing historically sedimented social structures of power and domination is, in his view, inseparable from activities that are geared towards a transformation of subjectivity. To engage in the transformation of societal relations for him means "to potentiate oneself and to develop oneself" (ibid.), while "to modify one's own personality means to modify the ensemble of these relations" (ibid, 670).

Against this backdrop, emancipation can be understood as a politics of subjectivity in which processes of individual and collective self-transformation, including the reworking of affects, desires and needs, constitute societal change and vice-versa. Emancipation can thus be specified as a politics of the production of new forms of relating to oneself and to others. 


\section{Emancipation as a critique of domination}

As Reinhard Koselleck has argued, a second major characteristic of the modern concept of emancipation is that it has been politicised. Whereas in the centuries before, "emancipation" had a purely juridical meaning, the concept acquired a political meaning in the early nineteenth century. It was "de-juridified" (Grass and Koselleck 1975, 160) although it never completely lost its juridical meaning. This process went hand in hand with a universalization of the meaning of "emancipation". In Roman Law, the act of emancipation referred to single individuals, and later - where the legal meaning remained dominant - to the act of granting equal rights to particular social groups defined by nation, religion or social status. In this sense, emancipation was always particularistic. However, this particularism - which remains a necessary element of emancipatory processes if they are to be forms of "self"-empowerment - was curtailed in the process of the politicalization of "emancipation". What was at stake in struggles over emancipation came to be seen not only as the enfranchisement of individuals or particular groups, but increasingly as a process of overcoming all forms of domination. "Emancipation," Koselleck writes, "provided the common denominator of justice for all demands aimed at the eradication of legal, social, political or economic inequality" (Koselleck 2002, 254). Although the concept became "multivalent and could signify completely different political meanings," it did not lose its "general plausibility" (ibid. 2545). On the contrary, on could say that "emancipation" through its various usages was constituted as an intersectional concept, not in the sense that those who used the term in the various contexts - feminists, abolitionists, socialists, proponents of cultural and religious equality - applied intersectional analyses of power and domination, but in the sense that it offered a shared political language for the various emancipatory struggles. Traveling across different social movements, the concept of emancipation carried the possibility of building political alliances and convergences without losing sight of the singularities of different forms of domination. Universalism, in this context, was not so much postulated as a norm against which political practices are judged but emerged as a political horizon and the possible result of the structural convergence of different emancipation processes.

In any case, Marx' critique of "political emancipation" - in contrast to what he called "human emancipation" - was a major contribution to the politicalisation and universalisation of "emancipation," in so far as he articulated emancipation as the opposite of domination, and not only as the admission of rights through a sovereign power. "Political emancipation," or the admission of human and citizen rights, Marx argued in On the Jewish Question, works on the basis of abstract equality but does not transform the conditions of inequality. 
As Wendy Brown has put it, "the 'constraint' from which political emancipation 'frees' the individual is politicized identity - the treatment of a particular social identity as the basis from deprivation of suffrage, rights or citizenship. But [...] emancipation from this constraint does not liberate the individual from the conditions constitutive or reiterative of the identity" (Brown 1995, 105). On the contrary, the admission of rights subjugates the individual to the state and civil society, and thus produces a new form of domination. ${ }^{4}$ What is crucial here is that, by revealing the limits of "political emancipation," Marx' shifted theoretical attention from the question of what kinds of rights and privileges should be granted to whom, to the question of to what extent societal relations are structured through forms of domination, including juridical and normative infrastructures. As a consequence, a new theoretical horizon emerged in which the main question to answer is: what is domination, and how does it work?

This shift of political and theoretical attention from struggles over rights to a critique of domination still poses a challenge for contemporary feminist theory, particularly for those strands of feminist theory that in one way or the other focus on "norms" - whether Habermasian attempts to find rational justifications or poststructuralist approaches that critically analyse the workings of norms and normativity. Even "anti-normative" approaches that have revealed the power effects of norms have largely neglected the analysis of the emergence of norms, i.e. the way in which certain norms are produced in and result from social, economic and political practices and relations. During the last decades, much attention has been paid to how political strategies and social imperatives, in particular neoliberalism and heteronormativity, are stabilised or destabilised through the ways in which subjects relate to and are shaped by hegemonic norms. However, the very concept of norm only captures some aspects of domination. In so far as they take "norms" as starting point, and fail to understand the ways in which normative infrastructures are produced within certain social, political and economic structures, analyses of power and domination remain largely incomplete.

In addition, this turn from social theory to questions of norms and normativity coincided with a shift of theoretical attention from the macrostructures of domination to the micro-physics of power. This shift has certainly been extremely fruitful for analysing power relations in daily life and in institutions and spheres once deemed apolitical, and has helped to overcome the pitfalls of economic reductionism and etatism or state-centrism. However, the theoretical focus on the fluid and dynamic forms of micropower that pervade the everyday has also led to a "refusal to reckon with deep social and economic powers entailed in liberal political pluralism" (Brown 2005, 114). In paradoxical accordance with the preference that has been given to the aspect of stability and reiteration within theoretical ac- 
counts of subjectivity, feminist political theory has, to a large extent, highlighted the malleability of power relations and avoided theorising about their structural stability.

A critical indicator for both the normative and the micro-political turn is certainly the disappearance of the notion of patriarchy from feminist theory, and with it the attempt to conceptualise gendered forms of domination. ${ }^{5}$ Even if it remains an open question as to whether "patriarchy" is a useful concept for theorising domination, the lack of any theoretical discussion pinpointing a specifically feminist notion of domination - that is, a notion that captures the specific forms of power and domination in gender relations - poses a serious problem. It is often assumed that every notion of domination capable of accounting for structural similarities across different societies, diachronically as well as synchronically, fosters Eurocentric and imperial perspectives, and indeed that has often been true of theories of patriarchy. Yet the converse also seems to be the case. To refrain from theoretical and political efforts to analyse both the similarities and the differences among modes of power and domination within and across different societies means to render feminist theory and political discourse susceptible to imperial strategies of culturalising gendered power relations, and to the externalisation of the problem of patriarchal domination onto "other cultures."

Victoria Browne proposes, for example, "a strategic reappraisal of 'patriarchy,' to recover a political interpretation of sexual violence/abuse in terms of structural male power, rather than individual aberration or an 'abuse of power"'(Browne 2014, 9). Referring to recent public debates on sexual violence that obliterate the question of gender hierarchy, she argues that "even if gender categories are multivalent and unstable, feminist analysis does need to be able to explain what makes something an instance of patriarchal power relations, rather than 'power relations' more generally" (ibid, 15). In the German context, recent debates about sexism and racism in the wake of the socalled "events in Cologne" have revealed how necessary it is to develop a political understanding of gendered forms of power, violence and domination that make intelligible the different, culturally inflected forms, and the ways in which these forms interfere with one another. ${ }^{6}$

In addition, the need for a more structural approach to power and domination in feminist theory also emerges in the context of recent pleas for a re-engagement of feminist theory with capitalism and the economic dimensions of domination. Diana Coole, for example, concludes that a timely understanding of emancipation requires the "recognition of an economic dimension that is complementary and integral to struggles for women's freedoms internationally and to the reinvention of embodied subjectivities as they negotiate the social structures of the twenty-first century" (Coole 2015, 545)..$^{7}$ The question of how to conceive of "the economy," and of how gendered forms of domination 
structure contemporary capitalism - a question that was debated in the disputes over capitalism and patriarchy in the 1970s - now re-emerges in a new context. Nancy Fraser's argument for a social "re-turn" of feminist theory, and her critique of neoliberal marketization are certainly one of the most explicit attempts to meet this challenge.

Fraser, to a large extent, builds on the analysis of Karl Polanyi who, in the 1940 s, envisioned the welfare state when he called for "social protection". In contrast to Polanyi, Fraser calls for "a new alliance of emancipation with social protection" (Fraser 2013, 240). ${ }^{8}$ She challenges Polanyi's ignorance vis-àvis the "oppressive forms of social protection" (ibid, 232), i.e. those regulations of the welfare state that stabilise forms of domination originating not in the economy but, for example, in patriarchal gender relations. Certainly, her reference to "emancipation" as a third strategy beyond social protection and marketisation helps to envision a new political space beyond neoliberal and social democratic policies. However, Fraser relegates patriarchal domination to a "non-economic" sphere. As a consequence, the question how the capitalist economy is entangled with and structured through gendered forms of power and domination remains undertheorised.

This is mainly the case because, in a Polanyian framework, economic processes are reduced to processes of marketisation, and certain entities circulate as commodities which, from a moral or political point of view, should not. This approach, however, neglects to ask why and under what conditions these entities, which Polanyi calls "fictitious commodities" come to circulate in markets." In particular, the processes of production and consumption that contribute to the emergence of new commodities are beyond the scope of the analysis. Taking processes of production and consumption into account, however, would reveal that a notion of "the economy" that is restricted to market processes is far too narrow. A critical analysis of these processes, in contrast, makes it necessary to take into account the political, legal and cultural procedures that constitute the production and consumption of the entities which, under certain circumstances, appear on markets as commodities. The commodification of biomaterials such as tissue, sperm or egg cells is a good example here. These processes can hardly be understood without analysing the normative frameworks, the technoscientific developments and imaginaries, and the transformation of modes of living that facilitate the emergence of these new commodities. ${ }^{10}$ As Athena Athanasiou has put it in her discussion with Butler, "there is nothing merely economic about economics" (Butler and Athanasiou 2013, 39), so that "we need to imagine and enact alternative (that is non-economistic) ways to deploy the concept of 'the economy' beyond its common sense" (ibid., 42). ${ }^{11}$

An alternative concept of the economy that accounts for processes of production, circulation and consumption including their political and cultural dimensions would overcome the tendency to regard gender relations and all 
forms of production and exchange that do not conform to commodity production or "the market" as inherently non-economic. It would thus be far better prepared to analyse the ways in which capitalist and non-capitalist economic practices co-constitute each other, and thus the ways in which gender relations shape and are shaped through economic processes. As Athanasiou puts it - albeit with a strong focus on normativity - "the challenge today is to better understand how the normativity of the economic in its neoliberal guise is inevitable and fundamentally linked to the reproduction of gender, sexual, kinship, desire, biopolitical (that is biocapital, human capital) normativity" (ibid). The current feminist re-engagements with economic issues and the critique of capitalism thus should, in my view, supplemented by a re-engagement with the concept of domination. The question of how gendered forms of domination are intertwined with other forms of domination, how articulations of domination vary within different societies, and how these different gendered forms of domination interfere with each other in contemporary globalised societies pose a serious challenge to feminist theory.

\section{Emancipation and the politics of temporality}

"Emancipation," from the late eighteenth century on, no longer referred to a single act within a given, preexistent order, but increasingly to a collective, political process of overcoming domination and transforming the present into a better future. In many cases, the notion acquired an anticipatory, utopian index and came to be connected with ideas of progress that proliferated in nineteenth-century philosophy of history and political discourse. Although the temporal meaning of emancipation was not strictly determined, ${ }^{12}$ most theoretical accounts and critiques of emancipation discuss its close relation to the notions of linear time and, as Laclau put it, "secularized eschatologies" (Laclau 1992, 128). In particular the ideas of evolutionary progress and of revolutionary change have been intensely criticised because they articulated the present as a merely transitory state on the way to a better future.

Poststructuralist theories, in contrast, have privileged an understanding of time as repetition, which to a large extent included "a draining of the future from the present" (Brown 2005, 103), or at least a downsizing of the anticipatory horizon. ${ }^{13}$ As a consequence, social and cultural transformations have largely come to be seen in terms of micrological displacements that occur in the processes of reiterating norms and meanings. Significantly, the emphasis on "revolution" that characterised titles in the 1970s like Women, The Longest Revolution (Juliet Mitchell) or The Dialectic of Sex: The Case for Feminist 
Revolution (Shulamith Firestone) more or less vanished. "Feminist revolution - which [...] carried the promise of remaking gender and sexuality that itself entailed a radical reconfiguration of kinship, sexuality, desire, psyche, and the relation of the private to the public," Brown stated in 2005, "went awry" (Brown 2005, 105). This "draining" of the future, or its re-articulation in terms of repetition and reiteration, however, is no less informed by a specific philosophy of time and history than are the ideas of progress or revolution. Whether to conceive of temporality in one way or the other certainly is not a question of truth or - ironically - of theoretical "progress" 14 but instead, it relates to certain theoretical and conceptual choices that need to be debated with regard to the avenues they might open or, on the contrary, block off. A reassessment of feminist critiques of linear time, and in particular of the ways in which the temporal dimension of the future has been articulated thus seems to be a timely endeavour in the context of a re-evaluation of the problems and potentials of the concept of emancipation.

Despite their differences, feminist philosophies of sexual difference, deconstructionism, and Deleuzian feminisms to a large extent operate with notions of time and change that build on a Heideggerian notion of repetition as constituting something new through recuperation of the past. "Repetition," ${ }^{15} \mathrm{Hei}-$ degger argues in Being and Time, is always a "repetition" of possibilities. It "neither brings back 'what is past', nor does it bind 'the present' back to what is 'outdated'. Arising from a resolute self-projection, repetition is not convinced by 'something past' in just letting it come back as what was once real. Rather, repetition responds to the possibility of existence that has been there." (Heidegger 1927/1996, 352-353) Repetition is thus cast as a process that engenders change and has an anticipatory and transformative dimension. In this vein, Luce Irigaray proposes “to make 'visible,' by an effect of playful repetition, what was supposed to remain invisible: the cover-up of a possible operation of the feminine in language" (Irigaray 1975/1985, 76). Though she does not assume a submerged feminine, Butler likewise conceives of the temporal process in which gender is constituted as a repetition and reiteration of norms. It is in the small fissures between the original version and its repetition that change occurs. As she puts it: It is "by virtue of ... reiteration that gaps and fissures are opened up as the constitutive instabilities in such constructions, as that which escapes or exceeds the norm, as that which cannot be wholly defined or fixed by the repetitive labor of that norm" (Butler 1993, 10). In both cases the primary focus is on the relation to the past and the present while the future is reduced to an effect of this relation. It is not conceived of as a dimension that shapes and structures the experience of temporality. In a similar way, Elizabeth Grosz who refers to Deleuze's reading of Nietzsche's idea of the eternal return states that "return is that what initiates and engenders difference" (Grosz 2004, 141). However, Grosz explicitly highlights the central status of 
the future, and argues that feminist political and cultural struggles are mainly geared towards "making the future different" (ibid, 14). Although she certainly does not devalue the temporal dimension of the future and formulates an understanding of temporality that integrates all three dimensions of past, present and future, she de-politicises the understanding of temporality. This is the case in so far as she equates temporality and becoming with the evolutionary process of life itself. "Life," Grosz puts it, "is a becoming beyond what it is because the past, not fixed in itself, never fixes or determines the present and future but underlies them, inheres in them, makes them rich in resources and forces them to differ from themselves" (ibid, 255). This is certainly a non-deterministic understanding that highlights the openness and unpredictability of processes of becoming. However by introducing evolutionary biology or "life itself" as foundational, ahistorical narrative through which the temporality of social change is articulated, the theoretical and political-ethical problems that initially provoked the critique of the "grand narration" of progress and revolution are not solved but reproduced.

Problems with regard to the understanding of temporality are certainly not confined to poststructuralist approaches but also persist in critical theory. As Amy Allen has argued, a "progressive philosophy of history ... still fuels the anticipatory-utopian aspects of critical theory" (Allen 2015, 524) and fosters the Eurocentric bias of post-Habermasian critical theory. An understanding of emancipation that overcomes such an understanding of historicity should, she argues, refer to Foucault's "philosophical-historical method" that problematizes "our present form of life ... by opening up lines of fragility and fracture" within it (ibid, 525). These lines of fragility and fracture destabilize relations of domination and thereby "serve as glimmers or anticipatory illuminations of other possible worlds" (ibid., 526).

In addition to Foucault, such an understanding of futurity and anticipation as resulting from a disruption of the present can borrow from Walter Benjamin's critique of progress, and in particular his concept of actualization. "Actualization," for Benjamin means the interruption and arrest of the historical process "in order to inaugurate another possibility" (Brown 2001, 156), as Wendy Brown put it. This idea of futurity results from a re-articulation of the past, which, for Benjamin, is "a making present, a materialization, even a particular production of the present" (ibid.). The past thus contains the possibilities of the future not in the sense that these possibilities just need to unfold; but through an active recuperation of failures and losses, these "lost" possibilities can be transformed into actual ones. In Benjamin's terminology, "remembrance" (Eingedenken) is a process which makes "the incomplete (happiness) into something complete, and the complete (suffering) into something incomplete" (Benjamin 1999, N 8,1; 471). Such a critical engagement with the past can be understood as working on both the personal and political 
levels. An example for this can be found in Sam McBean's reading of Marge Piercy's Women on the Edge of Time (1976). With regard to the main character Connie's personal and political and experiences, she concludes that a feminist understanding of futurity "might require considering how the incomplete, the unfinished or even the 'failures' of the past [...] open up unforeseen possibilities” (McBean 2014, 46). An emancipatory politics of subjectivity, thus involves critical recuperations of personal and of political "pasts" that constitute new possibilities of personal and societal relations. In contrast to the notion of repetition, a Benjaminian understanding of temporality thereby allows for a more radical understanding of change and transgression - of "leaps" into the past that produce an effective interruption, distortion and reconfiguration of the present.

With regard to the history of the concept of emancipation and its temporal index, it is however most important to acknowledge that instead of being inherently linked with the notion of progress, the temporal meaning of emancipation has been constantly rearticulated. The struggles over the question of how past, present and future relate to each other must themselves be seen as part of the multiple politics of emancipation. In light of the present economic, political, military, and ecological crises, it seems that once again, the timescales of feminist politics and the relations of past, present, and future need to be reinvented.

\section{Conclusion}

Throughout this article, I have argued that the concept of emancipation and its ambivalent legacies may prompt a rethinking of feminist theory and offer a useful springboard to scrutinise assumptions that are widely taken for granted. As is the case with other concepts of political philosophy and political language, such as freedom, autonomy or justice, it is probably the concept's constitutive openness that renders it so productive. Indeed, rather than designating an "abstract utopia" or a norm, "emancipation" seems best to be understood in a "negativistic" way, as Amy Allen has argued. As an ongoing process of critique and subversion, the meaning of emancipation thus depends on situated re-articulations. For developing such an open understanding of emancipation, the perspective of conceptual history is particularly helpful. In contrast to oversimplifying critiques of "emancipation" that reduce it to liberal equal rights policies, or worse to articulations of emancipation as an ideological norm to which people have to adjust, ${ }^{16}$ the history of the concept of emancipation reveals that the politicalisation and temporalisation of "emancipation" in the late eighteenth and early nineteenth centuries, which correlated with the 
emergence of a politics of subjectivity, constituted a political concept through which claims and hopes of overcoming domination that go far beyond liberal and neoliberal horizons, not to say their authoritarian complements, can be articulated. In this sense, "emancipation" is an indispensable concept of the political language of feminism.

\section{Endnotes}

1 In Undoing the Demos. Neoliberalism's Stealth Revolution Wendy Brown has recently argued that neoliberalism understood as "a peculiar form of reason that configures all aspects of existence in economic terms, is quietly undoing basic elements of democracy" (Brown 2015, 17). She claims that neoliberalism undermines all forms of subjectivity that do not fit the model of the homo economicus but belong to the preconditions of democratic political engagement and thus democracy itself. The recent rise of right-wing populist movements and parties throughout Europe that articulate feelings and experiences of dispossession in a way that reinforces neoliberal processes of de-solidarisation within, among and beyond European societies seems to confirm her analysis.

2 Bargetz refers to Jacques Rancière's concept of the "distribution of the sensible". She argues that "thinking through the distribution of emotions makes it possible to grasp the historically specific distribution of the sensible that privileges the emotions of certain people over those of others and, by doing so, it is also able to consider how politics are affectively translated." (Bargetz 2015, 92.)

3 Original translation: "men".

4 "Equality before the law," as Joan Scott summarizes Marx's argument, "works by abstracting individuals from the power relationships in which they are located. The extension of emancipation to previously excluded groups does not alter structures of domination in the social realm. Instead it naturalizes those structures by relegating them to civil society - removing them as objects of political attention" (Scott 2012, 150). The modern differentiation between state and civil society thus installs a particular form of domination.

5 Browne suggests that "patriarchy" which she understands as "a concept developed by feminist theorists in the 1970s to name the workings of male power, privilege, domination and violence" is a "silent or missing concept" in contemporary feminism (Browne 2014, 9). This does not mean that the concept of patriarchy has vanished entirely from feminist discourse, but it has not - since the early 1990s inspired much theoretical work.

6 On December 31, women who came to celebrate New Year's Eve in the city streets of Cologne were sexually assaulted en masse by mostly immigrant men who had gathered in front of the main station. Right-wing movements, parties and media immediately exploited these events for racist and anti-refugee campaigns. The German weekly FOCUS, for example, published a cover showing a white female body with marks of black hands against which the woman seeks to defend herself. On the subsequent discussion and the self-justification of the chief editor of FOCUS 
see Der Tagesspiegel, 11.1.2016. http://www.tagesspiegel.de/medien/focus-chef-verteidigt-umstrittenes-cover-medien-diskussion-geht-weiter-wir-bilden-ab-was-leider-passiert-ist/12810242.html. Feminists, in contrast, pointed to the patriarchal "blind spots" of the German law and the respective behaviour of the police: Not only had the police, although aware of the events, remained largely passive, but even those few men who could be identified and arrested could not be prosecuted for sexual assault because German law punishes sexual assaults only in very specific cases - for example, if the woman can prove she has bodily defended herself, which obviously can hardly be the case if the assault is rapid and unexpected.

7 See also Sigridur Thorgeirsdottir 2015. Dependency and Emancipation in the Debt-Economy: Care-Ethical Critique of Contractarian Conceptions of the Debtor-Creditor-Relation. Hypatia. A Journal of Feminist Philosophy Vol. 30, Is 3, 564-579.

8 Fraser argues that in the second half of the twentieth century, "struggles for emancipation," in particular by feminists, "directly challenged oppressive forms of social protection" (Fraser 2013, 232), and thus those regulations of the welfare state that stabilized forms of domination originating not in the economy, but in society. This led to an uneasy affiliation with neoliberal strategies of marketisation, so that the "dream of women's emancipation" was "harnessed to the engine of capital accumulation" (ibid., 240).

9 For Polanyi, land, labor and money are "fictitious" commodities because they are, originally, not produced for the market.

10 For a critical analysis of these processes see for example Melinda Cooper, Catherine Waldby 2014. Clinical Labor: Tissue Donors and Research Subjects in the Global Bioeconomy. Durham and London: Duke University Press.

11 Cf. Butler's earlier critique of Nancy Fraser's opposition between distribution and recognition: Judith Butler 1998. Merely Cultural? New Left Review Is 227, January $1998,33-44$.

12 Reading documents from the period reveals that temporalisation not only meant highlighting futurity and the expectation of a better "tomorrow"; it also meant linking contemporary struggles with historical ones and construing genealogies. Joseph T. Wilson, for example, opens his account of the abolition of slavery in the United States with a list of the successes of emancipation from the early twelfth to the late nineteenth century (Wilson 1881).

13 Brown here discusses the implications of the loss of the "promise of revolution" (Brown 2005, 102), and the process of mourning that follows this loss. "Mourning revolution is [...] mourning a particular kind of futurity, a specifically modernist kind of rightful expectation, a temporality we do not yet know to live without." (ibid., 103)

14 On this point see also Browne 2014.

15 Joan Stambaugh here and in the following translates "Wiederholung" as "retrieve".

16 Scott argues that an ideological understanding of emancipation prevails in contemporary debates about the place of Muslims in Western societies. In neo-racist discourse, "the issue is not so much whether to confer rights on or to extend equality to these newer residents of European nations, but whether they are psychologi- 
cally sufficiently emancipated and/or egalitarian to be eligible for full membership and permanent inclusion" (Scott 2012, 154). Sara Farris has further elaborated on this critique of "emancipation as an end without means," i.e. the articulation of "emancipation" - the internalization of Western "values"- as a subjective precondition for the full admission to political, economic, social and cultural rights (Farris 2014, 301).

\section{References}

AHMED, Sara 2010. The promise of happiness. Durham, N.C., and London: Duke University Press.

ALLEN, Amy 2015. Emancipation without Utopia: Subjection, Modernity and the Normative Claims of Feminist Critical Theory. Hypatia. A Journal of Feminist Philosophy, 30:3, Summer 2015, 513-29.

ALLEN, Amy 2008. The Politics of Our Selves. Power, Autonomy, and Gender in Contemporary Critical Theory. New York: Columbia University Press.

BARGETZ, Brigitte 2015. The Distribution of Emotions: Affective Politics of Emancipation. Hypatia. A Journal of Feminist Philosophy, 30:3, Summer 2015, 580-96.

BENJAMIN, Walter 1999. The Arcades Project, translated by Howard Eiland and Kevin MacLaughlin. London and Cambridge, Mass: Belknap Press.

BENHABIB, Seyla 1995. Feminism and postmodernism. In Seyla Benhabib, Judith Butler, Drucilla Cornell (eds), Nancy Fraser Feminist contentions: A philosophical exchange. London and New York: Routledge.

BRAIDOTTI, Rosi 2002. Metamorphoses: Towards a materialist theory of becoming. Cambridge, UK: Polity Press.

BROWN, Wendy 2015. Undoing the Demos. Neoliberalism's Stealth Revolution. New York: Zone Books.

BROWN, Wendy 2005. Feminism Unbound: Revolution, Mourning, Politics. In Edgework. Critical Essays on Knowledge and Politics. Princeton: Princeton University Press, 98-117.

BROWN, Wendy 2001. Introduction. In Politics out of History. Princeton: Princeton University Press, 3-17.

BROWN, Wendy 2001. Spectres and Angels: Benjamin and Derrida. In Politics out of History. Princeton: Princeton University Press, 138-177.

BROWN, Wendy 1995. Rights and Losses. In States of Injury. Power and Freedom in Late Modernity. Princeton: Princeton University Press, 96-134.

BROWNE, Victoria 2014. The persistence of patriarchy: Operation Yewtree and the return to 1970s feminism. Radical Philosophy, Is 188, Nov/Dec 2014, 9-19.

BUTLER, Judith 1998. Merely Cultural? New Left Review, Is 227, January 1998, $33-44$.

BUTLER, Judith 1993. Bodies that matter. On the discursive limits of 'sex'. London and New York: Routledge.

BUTLER, Judith 1990. Gender trouble. London and New York: Routledge. 
BUTLER, Judith, Athena Athanasiou 2013. Dispossesion: The Performative in the Political. Cambidge and Malden: Polity Press.

COOLE, Diana 2015. Emancipation as a Three-Dimensional Process for the Twenty-First Century. Hypatia. A Journal of Feminist Philosophy, 30:3, Summer 2015, 530-46.

COOPER, Melinda, Catherine Waldby 2014. Clinical Labor: Tissue Donors and Research Subjects in the Global Bioeconomy. Durham and London: Duke University Press.

Der Tagesspiegel: "Focus"-Chef verteidigt umstrittenes Cover. Medien-Diskussion geht weiter. "Wir bilden ab, was leider passiert ist", 11.1.2016, http://www.tagesspiegel.de/medien/focus-chef-verteidigt-umstrittenes-cover-medien-diskussion-geht-weiter-wir-bilden-ab-was-leider-passiert-ist/12810242.html, last access 1.6.2016.

FARRIS, Sara R. 2014. From the Jewish Question to the Muslim Question. Republican Rigorism, Culturalist Differentialism and Antinomies of Enforced Emancipation. Constellations, Vol 21, Is 2, June 2014, 296-307.

FOUCAULT, Michel 1984. What is Enlightenment? Paul Rabinow (ed.), The Foucault Reader. New York: Pantheon Books, 32-50.

FRASER, Nancy 2015. Between Marketization and Social Protection: Resolving Feminist Ambivalence. In Fortunes of Feminism. London: Verso, 53-82.

FRASER, Nancy 2015. Struggle over Needs: Outline of a Socialist-Feminist Critical Theory of Late-Capitalist Political Culture. In Fortunes of Feminism. London: Verso, 53-82.

GRAMSCI, Antonio 1999. Selections from the Prison Notebooks, edited and translated by Quentin Hoare and Geoffrey Nowell Smith. London: ElecBook.

GROSZ, Elizabeth 2004. The Nick of Time. Politics, Evolution, and the Untimely. Durham und London: Duke University Press.

HEIDEGGER, Martin 1996. Being and Time (1927), translated by Joan Stambaugh. Albany, NY: SUNY Press.

IRIGARAY, Luce 1985. The power of discourse and the subordination of the feminine (1975). In This Sex Which Is Not One. Ithaca and New York: Cornell University Press.

KANT, Immanuel 2003. An answer to the question: What is enlightenment? (1784). In Political Writings, edited by H. Reiss. Cambridge: Cambridge University Press.

KOSELLECK, Reinhart 2002. The limits of emancipation: A conceptual-historical sketch. In The practice of conceptual history: Timing history, spacing concepts. Stanford: Stanford University Press.

KOSELLECK, Reinhart, Karl Martin Grass 1992. Emanzipation. In Otto Brunner, Werner Conze, Reinhart Koselleck (eds.), Geschichtliche Grundbegriffe: Historisches Lexikon zur politisch-sozialen Sprache in Deutschland, Vol. 2. Stuttgart: Klett-Cotta, 153-97.

LACLAU, Ernesto 1992. Beyond Emancipation. In Jan Nederveen Pieterse (ed), Emancipations, Modern and Postmodern. London: Sage, 121-38.

MCBEAN, Sam 2014. Feminism and futurity: revisiting Marge Piercy's Woman on the Edge of Time. Feminist Review, Vol. 107, May 2014, 37-56.

SCOTT, Joan Wallach 2012. The vexed relationship of emancipation and equality. 


\section{Susanne Lettow: Dimensions of Emancipation}

History of the Present, 2:2, 148-68.

THORGEIRSDOTTIR, Sigridur 2015. Dependency and Emancipation in the Debt-Economy: Care-Ethical Critique of Contractarian Conceptions of the Debtor-Creditor-Relation. Hypatia. A Journal of Feminist Philosophy, 30:3, 56479.

WILSON, Joseph T. 1881. Emancipation: Its course and progress from 1102 to 1875. Hampton, Va.: Normal School Steam Press Print. 